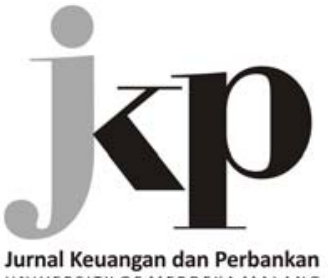

UNIVERSITY OF MERDEKA MALANG

Article history:

Received: 2019-11-14

Revised: 2019-12-10

Accepted: 2020-01-23

Keywords:

ASEAN; Digital banking;

Banking financial performance

JEL Classification: G21, G32

Kata kunci:

ASEAN; Digital banking;

Kinerja keuangan perbankan

$\triangle$ Corresponding Author:

Muhammad Sri Wahyudi

Suliswanto:

Tel. +62 341551149

E-mail: al.ayudie@gmail.com

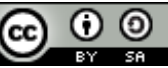

This is an open access

article under the CC-BY-SA license

\section{Financial banking performance of ASEAN-5 countries in the digital era}

\author{
Nazaruddin Malik, Arlini Oktavia, Muhammad Sri Wahyudi Suliswanto, \\ Firdha Aksari Anindyntha \\ Department of Economic Development, Faculty Business and Economics, Universitas \\ Muhammadiyah Malang \\ Jl. Raya Tlogomas No.246 Malang, 65144, Indonesia
}

\begin{abstract}
The improvement of technology and information create a digital era in all aspects of the economy, one example is in the banking sector. This study aims to find out and compare the banking financial performance in Indonesia, Singapore, Malaysia, Thailand and the Philippines in the period 2012-2017. The model used in hypothesis testing using one-way ANOVA parametric test. Furthermore, using the panel regression analysis and results from coefficient of determination (R2) from the regression to see the influence of digital era on ASEAN banking financial performance. The results of the study showed that the financial performance of ASEAN-5 banks differ significantly with other ASEAN countries and the average value of Indonesian banking financial performance showed better results than the other four ASEAN countries on CAR, ROA, and NIM ratios. However, on average the LDR ratio shows that Singapore, Malaysia, and Thailand are better than Indonesia. There are two of five variables that have a significant effect on bank profitability, namely the implementation of digital banking and the funding variables from third parties in banks. Other variables that are not significant are completeness in information of digital banking provided by the bank, the number of internet banking users of each bank, and the amount of credit channeled by the bank.
\end{abstract}

\section{Abstrak}

Peningkatan teknologi dan informasi menciptakan era digital di semua aspek ekonomi, salah satu contohnya adalah di sektor perbankan. Penelitian ini bertujuan untuk mengetahui dan membandingkan kinerja keuangan perbankan di Indonesia, Singapura, Malaysia, Thailand dan Filipina pada periode 2012-2017. Model yang digunakan dalam pengujian hipotesis menggunakan uji parametrik ANOVA satu arah. Selanjutnya, menggunakan analisis regresi panel dan hasil dari koefisien determinasi $(R 2)$ dari regresi untuk melihat pengaruh era digital terhadap kinerja keuangan perbankan ASEAN. Hasil penelitian menunjukkan bahwa kinerja keuangan bank-bank ASEAN-5 berbeda secara signifikan dengan negara-negara ASEAN lainnya dan nilai rata-rata kinerja keuangan perbankan Indonesia menunjukkan hasil yang lebih baik daripada empat negara ASEAN lainnya pada rasio CAR, ROA, dan NIM. Namun, secara rata-rata rasio LDR menunjukkan bahwa Singapura, Malaysia, dan Thailand lebih baik daripada Indonesia. Ada dua dari lima variabel yang memiliki pengaruh signifikan terhadap profitabilitas bank, yaitu penerapan perbankan digital dan variabel pendanaan dari pihak ketiga di bank. Variabel lain yang tidak signifikan adalah kelengkapan informasi perbankan digital yang disediakan oleh bank, jumlah pengguna internet banking masing-masing bank, dan jumlah kredit yang disalurkan oleh bank.

How to Cite: Malik, N., Oktavia, A., Suliswanto, M. S. W., \& Anindyntha, F. A. (2020). Financial banking performance of ASEAN-5 countries in the digital era. Jurnal Keuangan dan Perbankan, 24(1), 117-130. https:/ / doi.org/10.26905/jkdp.v24i1.2641 


\section{Jurnal Keuangan dan Perbankan \\ Volume 24, Issue 1, January 2020: 117-130}

\section{Introduction}

The digital era nowadays is signed by the widespread use of digital technology as a result of technology and information advancement as a real manifestation of globalization. Globalization provides great opportunities in terms of openness between countries to bring about integration or cooperation that intentions to benefit various parties. One of integration or cooperation practices is the emergence of ASEAN. The establishment of ASEAN is an effort to strengthen cooperation between ASEAN countries. In addition, it is also an evolutionary struggle to adjust the perspective so that discussions on domestic issues can be carried out more openly for the good of the region without ignoring the main principles of ASEAN.

The ASEAN Community consists of three pillars which comprise cooperation in the economic field, namely: ASEAN Security Community (ASC), ASEAN Economic Community (AEC) and ASEAN Socio-Cultural Community (ASCC). One of the ASEAN community collaborations is the inauguration of the ASEAN Economic Community (AEC). Suroso (2015), in an article published by the Financial Education and Training Agency of the Ministry of Finance at the IX Summit in Bali, claimed that Indonesia is one of the countries initiating the establishment of the MEA in 2015. One of the power sectors in MEA is free trade which has been started since 2015 whereas the banking sector will start in 2020, where it is in the digital era due to the rapid advances in technology and information.

AEC creates financial integration in the ASEAN region so that it demands the banking industry in each country to improve competitiveness with ASEAN countries through performance that is illustrated by the bank's financial performance. The success of bank performance is of course also supported by the use of digital banking because according to Shaukat \& Zarullah (2010), most information technology users are from the financial sector, especially banks. Banking needs to process data elec- tronically, reach customers in all regions of the country, and provide real time services so that digital banking can contribute to increasing profitability which has an impact on improving bank financial performance. In line with the results of research from Sumra et al. (2011) which showed that e-banking adoption was able to provide a significant rate of return for banks.

The presence of banking sector integration can also be a threat to the domestic banking industry when banks are unable to compete in terms of financial performance. This integration makes it easier for foreign banks to enter the national banking industry (Fajarini, 2017). In the face of the MEA, domestic banks must be able to compete with other ASEAN member banks, especially in terms of banking performance which is illustrated through financial performance. Although Wulandari (2015) states that Indonesia's average banking financial ratios are better than the average of the other three ASEAN countries (Malaysia, Thailand, and Singapore) in the ROA and NIM ratios, while the NPL, NOP, LDR, GCG, and CAR ratios show a better average for other ASEAN countries.

This is similar with Wahyuni \& Sukirno (2016) also stated that the average financial ratios of Indonesian banks are better than the average of the other three ASEAN countries in the ratio of NPL, ROA, NIM and CAR, while the LDR ratio shows better average other ASEAN countries (Thailand and the Philippines). Financial performance is part of the whole performance of the bank. An overview of the development of the company's financial performance can be obtained by analyzing the company's financial data, and it will be reflected in the financial statements (Nastiti, 2009).

Research conducted by Subuh, Zuhroh \& Abdullah (2016) which discussed the comparative financial performance of national banks and foreign banks in 2010-2014 showed that the performance of foreign banks was better than the financial performance of national banks. Bank financial performance 
is part of the overall performance of the bank. The overall performance of the bank is a representation of the achievements of the bank in its operations, both concerning the aspects of finance, marketing, raising and channeling of funds, technology, and human resources. Based on this, it can be concluded that the bank's financial performance is an illustration of the bank's financial condition in a certain period, both concerning the aspect of fund-raising and the channeling of funds which is usually measured by indicators of capital adequacy, liquidity, and bank profitability. Analysis of bank financial performance or bank financial analysis is a critical review process of bank finances about reviewing financial report data, calculating, measuring, interpreting, and providing solutions to banks in a given period (Abdullah, 2003).

Along with the increasing use of digital technology by the community, the banking sector is also getting more intense employing digital technology (digital banking) to support all services and trying to response what is needed by the community through e-banking. Simpson (2002) said that e-banking term referred to the banking method used by customers to conduct financial transactions electronically which is supported by the internet without having to come directly to the bank. E-banking can be classified in several forms including, computer banking, telephone, and handphone, as well as online based banking by utilizing internet networks (internet banking) (Mihalciuc, Apetri, \& Bonaventure, 2008).

Arnaboldi \& Claeys (2010) found that the performance of bank groups using internet banking was not entirely lower than ROAE and ROAA, the study was conducted on 60 of the largest banks in Europe, the operational costs were also not higher. The success of banks in implementing Internet banking depends on the client's deposit structure. The adoption of internet banking is much influenced by external factors such as the percentage of households that use the internet and the development of the internet in the community. Internet banks cause com- petition between banks to become increasingly competitive and transparent.

There are several benefits of using e-banking in the digital era among others are providing convenience and saving customers time because they do not need to come to the bank, can transact anywhere without time limits, and banks have the opportunity to attract more public interest to become customers so as to increase banks' profits (Okibo \& Wario, 2014).

In European countries, internet banking has very strong causality with bank profitability. Countries in Europe that use internet banking in their banking sector are more advanced than other European countries, tend to have strong bank financial performance (Akhisar, Tunay, \& Tunay, 2015). These results support research from Oyewole, Abba, \& El-Maude (2013) which states that e-banking has a significant positive impact on banking performance as measured by the profitability aspects of ROA and NIM in Nigerian banks.

The results are different from the countries of Turkey and Bangladesh, Oney et al. (2013) stating that e-banking has a negative effect on banking performance in terms of the NIM ratio in Turkey in the short term because the development of online banking (digital banking) is a gradual and costly process quite high at the beginning. In Bangladesh, e-banking began to contribute positively to bank ROE after a gap of two years because at the beginning of the first year the adoption of e-banking still had a negative impact. E-banking adoption also has a positive effect on ROA and NIM variables, but it is not significant (Siddik et al., 2016).

Likewise, the ASEAN countries are still in the stage of evolution in digital banking. This is indicated by the internet users and digital buyers' share of the total population in ASEAN, which is relatively low compared to countries in the Americas, Europe and some developed countries in Asia. But in fact to date, ASEAN-5 countries have a positive growth trend each year in the penetration of digital bank- 
ing, which is shown through increased use of internet banking (BBVA Research, 2017).

Previous studies have proved inconsistent results from the impact of digital banking on the performance of banks in various countries. Therefore, researchers are interested in seeing how digital influences on banking financial performance when applied not only in one country but also in several countries on one region. The difference with the previous research is before looking at the effect of digital banking on financial performance, especially the different tests of financial performance between banks and financial performance are represented by profitability ratios, namely NIM because there are many differences in the results of research between digital banking and NIM.

The purpose of this research is to find out how the level of financial performance of banks and compare the financial performance of banks in ASEAN5 countries, and see the effect of digital banking on bank financial performance, especially the NIM profitability ratio which expect to have a positive impact as a banking strategy in ASEAN countries 5 in facing financial sector competition internationally. The research focuses on the analysis and comparison of the financial performance of the country's banks incorporated in ASEAN-5 as the founding countries of ASEAN (as original members), namely Indonesia, Singapore, Malaysia, Thailand, and the Philippines.

\section{Method, Data, and Analysis}

This research applies descriptive methods that describe and analyze the financial performance of banks in ASEAN-5 countries in the 2012-2017 period. Descriptive method is a method of describing an objective situation or a certain event based on obvious facts which is then accompanied by attempts to draw general conclusions on historical facts (Nawawi \& Martini, 1994). The next step after knowing the financial performance of banks in ASEAN-5 countries is to explore the relationship between the uses of digital banking, which continues to grow, with banking financial performance.

The population in this study involved all banks in Indonesia, Singapore, Malaysia, Thailand, and the Philippines. While the sample consisted of 21 banks by applying a purposive sampling method. The criteria used in the purposive sampling consisted of three, including: (1) banking is not an Islamic bank, (2) banks that fulfill digital banking index more than others.

Table 1. List of 21 research samples

\begin{tabular}{lll}
\hline \multicolumn{1}{c}{ Bank } & \multicolumn{1}{c}{ Country } & \multicolumn{1}{c}{ Bank } \\
\hline DBS Bank & Singapore & Bank Mandiri \\
OCBC Bank & & Bank Rakyat Indonesia \\
United Overseas Bank & & Bank Central Asia \\
& & Bank Nasional Indonesia \\
& & Bank Bukopin \\
Maybank & Malaysia & Bangkok Bank \\
CIMB & & Siam Commercial Bank \\
Public Bank Berhad & & Krung Thailand Bank \\
Ambank & & Kasikorn Bank \\
RHB Bank & Thanacart Bank \\
Metropolitan Bank and Trusts Company & & \\
Bank of The Philippine Islands & & \\
Bank De Oro Bank & & \\
\hline Source: Forbes Magazine (Data processed, 2018) & &
\end{tabular}


The variable used in this study to analyze financial performance is based on three banking ratios, namely the capital adequacy ratio, liquidity ratio, and profitability ratio. The capital adequacy ratio uses the Capital Adequacy Ratio (CAR) which compares between capital and Risk Weighted Assets (RWA). The liquidity ratio uses the Loan to Deposit Ratio (LDR) obtained from a comparison between the composition of the amount of credit provided and the number of public funds and own capital while profitability ratios are seen from Return on Assets (ROA), which is a ratio that compares net income with total assets and Net Interest Margin (NIM), which is a ratio of the amount of net interest income to productive assets owned by a bank. We obtained the data from the websites of each bank.

The data analysis technique used in this study is ratio analysis using the method of measuring the financial performance of banking companies. Afterward, the results of the analysis of financial ratios of each bank in different countries will be tested using the analysis method test with a normality test for data distribution and ANOVA One-Way test.

The next analysis is regression panel from the results of the bank's financial profitability ratios for each country studied which is used to explain how much influence digital banking has on banking financial performance through the coefficient of determination $\left(\mathrm{R}^{2}\right)$. The analysis technique in panel data consists of three, namely Pooled OLS Model, Fixed Effect Model (FEM) and Random Effect Model (REM). Furthermore, from the three models will be test to determine which model is appropriate. Test that can be used are Chow Test, Hausman Test, and
LM Test. The regression equation model is as follows:

$$
\begin{aligned}
N I M= & \alpha+\beta_{1} \text { INFORMATION }+\beta_{2} \text { DIGITAL }+\beta_{3} \text { USER }+ \\
& \beta_{4} \text { CREDIT }+\beta_{5} D P K+\varepsilon
\end{aligned}
$$

The variable to find out the effect of digital banking where the implementation is explained by the dummy variable of completeness in information of digital banking provided by the bank (INFORMATION), then the implementation of digital banking was measured using an index digital (DIGITAL) from Cisco Consulting (Bradley et al., 2014). Number of internet banking users of each bank (USER) on bank financial performance that is the profitability ratio (NIM). User variable indicates the internet usage. The increasing use of the internet will encourage the potential for the development of digital banking and also the ease of online financial transactions (Iman, 2016; Rahadiyan \& Sari, 2019). Then it also add the amount of credit channeled by the bank (CREDIT) and the funding from third party in bank (DPK) as a control variable. Financial performance of the bank is represented by profitability ratios that is NIM because NIM is the main indicator of profitability that reflects the way banks generate profits from lending activities (intermediation function).

\section{Results}

\section{Descriptive analysis}

Table 2 shows that the average value of CAR for each ASEAN-5 country is different in terms of capital ratio. The average CAR value of all ASEAN-

\begin{tabular}{|c|c|c|c|c|}
\hline & Minimum & Maximum & Mean & Std.Deviation \\
\hline Singapore & 15.30 & 19.10 & 16.6200 & 1.05573 \\
\hline Malaysia & 13.90 & 19.29 & 15.8620 & 1.47550 \\
\hline Thailand & 14.79 & 18.32 & 16.4607 & 1.16090 \\
\hline Indonesia & 14.20 & 22.91 & 18.2547 & 2.90267 \\
\hline Philippines & 12.40 & 19.20 & 15.2627 & 1.77590 \\
\hline
\end{tabular}

Table 2. CAR descriptive analysis 
5 countries is good or healthy when referring to the standards set by the Bank for International Settlements (BIS), the amount of CAR per bank is at least $8 \%$. On average, the highest average CAR value is Indonesian banks, followed by Singapore, Thailand, Malaysia, and the Philippines. The high CAR ratio of Indonesian banks is because the Bank Indonesia regulation that requires a minimum CAR of 8 percent results in banks always trying to keep the CARs possessed by the provisions. Therefore, the capital aspect in banking financial performance represented by the Capital Adequacy Ratio (CAR) is considered strong enough to compete healthily with other banks in facing the ASEAN Economic Community (MEA).

Table 3 displays the average value of ROA of each ASEAN-5 country contrarily in the profit ratio. Banks are financial institutions whose main function is to provide intermediary services and other financial services to companies and households with the aim of maximizing the owner's wealth (Asmirawati, 2010). Viewed from the average of each country, Indonesia has the highest average Return on Assets (ROA) which is equal to 3,6413 percent and also the only country whose average ROA is above the ASEAN average whereas the other 4 ASEAN countries are below the ASEAN average. Thailand has an average value of ROA of 1.464 per- cent, and the Philippines is 1.4547 percent, Malaysia is 1.2893 percent, and Singapore is 1.038 percent. The high ROA in Indonesia is caused by, among others, the average level of low overhead costs and the ability of banks to create high operating income. As well, the level of bank profits reflected in the high ROA in Indonesia shows that bank assets have been used optimally to gain bank income so that banks in Indonesia have a deeper capability to generate profits from total assets owned when compared to 4 other ASEAN banks.

Based on Table 4, the average NIM value of each ASEAN-5 country also differs from the profit ratio. The average value of NIM for Singapore, Malaysia, Thailand, and Philippines is in the poor category while Indonesia is good or healthy because if it refers to the standards set by Bank Indonesia, the amount of NIM for each bank is at least 6 percent. The highest average NIM ratio was also in Indonesian banking, which amounted to 6.7467 percent, then Philippines 3.3507 percent, followed by Thailand at 2.8333 percent, Malaysia at 2.5073 percent and then Singapore state banks at 1.7187 percent. The high NIM in Indonesia illustrates the greater profits earned from interest income and will affect the reliability of the bank.

Table 3. ROA descriptive analysis

\begin{tabular}{lcccc}
\hline & Minimum & Maximum & Mean & Std.Deviation \\
\hline Singapore & 0.91 & 1.19 & 1.0380 & .09814 \\
Malaysia & 0.65 & 1.90 & 1.2893 & .43578 \\
Thailand & 1.02 & 2.10 & 1.4640 & .34417 \\
Indonesia & 1.95 & 5.15 & 3.6413 & .95979 \\
Philippines & 1.00 & 1.91 & 1.4547 & .28002 \\
\hline
\end{tabular}

Table 4. NIM descriptive analysis

\begin{tabular}{lcccc}
\hline & Minimum & Maximum & Mean & Std.Deviation \\
\hline Singapore & 1.62 & 1.87 & 1.7187 & 0.06632 \\
Malaysia & 2.20 & 3.07 & 2.5073 & 0.26174 \\
Thailand & 2.16 & 3.30 & 2.8333 & 0.40335 \\
Indonesia & 5.40 & 8.55 & 6.7467 & 1.25627 \\
Philippines & 2.85 & 3.90 & 3.3507 & 0.28574 \\
\hline
\end{tabular}


Table 5 indicates that the average LDR value of each ASEAN- 5 country is dissimilar in the liquidity ratio. The average value of the LDR of a Philippine country includes unfavorable or unhealthy, while for banks in Thailand, Singapore, Malaysia and Indonesia in good or healthy categories when referring to the standards set by Bank Indonesia the size of a healthy LDR is at $85-110 \%$. The liquidity aspect is clarified through the Loan to Deposit Ratio (LDR) ratio, the highest average LDR value, namely Thailand banking at 92.291 percent, then Malaysian banking at 90.88 percent and Singapore banking at 85.12 percent. Whereas the other two countries that are members of ASEAN- 5 countries, namely Indonesian and Philippine banks, have an average LDR value below the ASEAN-5 LDR, which is 82.925 percent and 69.391 percent. The high LDR in Thailand banks shows the ability of banks to carry out the intermediary function, namely the high level of distribution of funds to the public in the form of loans or loans for funds collected from the public whereas Indonesia's banking position is below the ASEAN-5 country average. This shows that Indonesian banks only accomplished to raise large amounts of funds but were not balanced by channels in the form of loans that generated a profit for the bank.

\section{Data Normality Test}

The data normality test is done with the aim of testing whether the data in the regression model is normally distributed or not normal. The K-S test was preferred in this study because it wanted to compare the distribution of observations with theoretical distributions. Based on estimate, the results of the data are normally distributed except for the Return on Assets (ROA) ratio and the Net Interest Margin (NIM) ratio. Data abnormalities are overcome by transforming data. Data transformation is done by not changing data even though data values change. With this adjustment, the data changes to normal.

\section{One Way ANOVA Test}

The ANOVA test was carried out after testing the normality of the data; it was conducted with the aim of testing whether the mean or mean of each test variable CAR, ROA, NIM, and LDR differed significantly or not.

Based on estimate, it can be seen that the $F$ value of CAR, LDR, ROA, and NIM has a probability of 0,000 , meaning $p<0.05$, so that the four sample groups have different CARs, LDRs, ROAs, and NIMs. First, based on the capital aspect, testing of the hypothesis shows the results of rejecting $\mathrm{H} 0$ and accepting $\mathrm{H}_{1}$, which means that there are significant differences from the aspect of the capital of financial performance between Indonesian banks and four other ASEAN countries. Based on the liquidity aspect, the results of testing on hypothesis 1 show that rejecting $\mathrm{H}_{0}$ and accepting $\mathrm{H}_{1}$ are significant differences in liquidity aspects in/ banking financial performance. In terms of the aspect of profitability, the test results show that rejecting $\mathrm{H}_{0}$ and accepting $\mathrm{H}_{1}$ are significant differences between the financial performance of Indonesian banks and the financial per-

Table 5. LDR descriptive analysis

\begin{tabular}{|c|c|c|c|c|}
\hline & Minimum & Maximum & Mean & Std.Deviation \\
\hline Singapore & 82.90 & 88.50 & 85.1200 & 1.64021 \\
\hline Malaysia & 84.20 & 95.60 & 90.8800 & 3.18819 \\
\hline Thailand & 86.57 & 97.00 & 92.1793 & 3.58468 \\
\hline Indonesia & 68.60 & 92.10 & 82.9253 & 6.43539 \\
\hline Philippines & 56.00 & 82.50 & 69.3913 & 7.04692 \\
\hline
\end{tabular}


formance of the four other ASEAN countries. Thus, it means that all variables reject $\mathrm{H} 0$ and support $\mathrm{H} 1$, which is a significant difference in financial performance based on the ratio of capital, profitability, and liquidity in ASEAN-5 banks.

\section{Post Hoc Test}

Post Hoc Test is used to test how big is the difference in banking financial performance between countries. ASEAN-5 countries have differences from each other, and this test can see significant differences between countries.

Based on Table 6, the liquidity aspect illustrated by the LDR ratio shows a significant differ- ence between Singapore and Philippines of 15.73 percent, between Malaysia and Singapore at 5.76 percent, between Malaysia and Indonesia at 7.95 percent, between Malaysia and Philippines as much as 21.48 percent, between Thailand and Singapore by 7.05 percent, between Thailand and Indonesia by 9.25 percent, between Thailand and Philippines at 22.79 percent, and between Indonesia and Philippines at 13.53 percent.

The capital aspect based on the CAR ratio demonstrates the results of the most significant differences between the countries of Indonesia and Malaysia and the Philippines, each with a significance of 2.39 percent and 2.99 percent.

Table 6. Post Hoc Test Results

\begin{tabular}{|c|c|c|c|c|c|c|c|}
\hline \multirow{2}{*}{ Dependent Variable } & \multirow{2}{*}{ (I) Country } & \multirow{2}{*}{ (J) Country } & \multirow{2}{*}{$\begin{array}{c}\text { Mean } \\
\text { Difference } \\
\text { (I-J) }\end{array}$} & \multirow{2}{*}{$\begin{array}{l}\text { Std. } \\
\text { Error }\end{array}$} & \multirow{2}{*}{ Sig. } & \multicolumn{2}{|c|}{$\begin{array}{c}95 \% \\
\text { Confidence Interval }\end{array}$} \\
\hline & & & & & & $\begin{array}{l}\text { Lower } \\
\text { Bound }\end{array}$ & $\begin{array}{l}\text { Upper } \\
\text { Bound }\end{array}$ \\
\hline \multirow[t]{8}{*}{$L D R$} & Singapore & Philippines & $15.72867^{*}$ & 1.76468 & .000 & 10.7873 & 20.6700 \\
\hline & Malaysia & Singapore & $5.76000^{*}$ & 1.76468 & .014 & .8186 & 10.7014 \\
\hline & & Indonesia & $7.95467^{*}$ & 1.76468 & .000 & 3.0133 & 12.8960 \\
\hline & & Philippines & $21.48867^{*}$ & 1.76468 & .000 & 16.5473 & 26.4300 \\
\hline & Thailand & Singapore & $7.05933^{*}$ & 1.76468 & .001 & 2.1180 & 12.0007 \\
\hline & & Indonesia & $9.25400^{*}$ & 1.76468 & .000 & 4.3126 & 14.1954 \\
\hline & & Philippines & $22.78800^{*}$ & 1.76468 & .000 & 17.8466 & 27.7294 \\
\hline & Indonesia & Philippines & $13.53400^{*}$ & 1.76468 & .000 & 8.5926 & 18.4754 \\
\hline \multirow[t]{2}{*}{$C A R$} & Indonesia & Malaysia & $2.39267^{*}$ & .65765 & .005 & .5512 & 4.2342 \\
\hline & & Philippines & $2.99200^{*}$ & .65765 & .000 & 1.1505 & 4.8335 \\
\hline \multirow[t]{4}{*}{$R O A$} & Indonesia & Singapore & $2.60333^{*}$ & .18704 & .000 & 2.0796 & 3.1271 \\
\hline & & Malaysia & $2.35200^{*}$ & .18704 & .000 & 1.8283 & 2.8757 \\
\hline & & Thailand & $2.17733^{*}$ & .18704 & .000 & 1.6536 & 2.7011 \\
\hline & & Philippines & $2.18667^{*}$ & .18704 & .000 & 1.6629 & 2.7104 \\
\hline \multirow[t]{8}{*}{ NIM } & Malaysia & Singapore & $.78867^{\star}$ & .22482 & .007 & .1591 & 1.4182 \\
\hline & Thailand & Singapore & $1.11467^{*}$ & .22482 & .000 & .4851 & 1.7442 \\
\hline & Indonesia & Singapore & $5.02800^{*}$ & .22482 & .000 & 4.3985 & 5.6575 \\
\hline & & Malaysia & $4.23933^{*}$ & .22482 & .000 & 3.6098 & 4.8689 \\
\hline & & Thailand & $3.91333^{*}$ & .22482 & .000 & 3.2838 & 4.5429 \\
\hline & & Philippines & $3.39600^{*}$ & .22482 & .000 & 2.7665 & 4.0255 \\
\hline & Philippines & Singapore & $1.63200^{*}$ & .22482 & .000 & 1.0025 & 2.2615 \\
\hline & & Malaysia & $.84333^{*}$ & .22482 & .003 & .2138 & 1.4729 \\
\hline
\end{tabular}


The profitability aspect illustrated by the ROA ratio shows the significance of the results that occur between Indonesia and four other ASEAN countries. Each of the results of Indonesia's significance with Singapore is 2.60 percent, the average significance of Indonesia with Malaysia is 2.35 percent, the average significance of Indonesia with Thailand is 2.17 percent, and the average significance of Indonesia with the Philippines is 2.18 percent.

In terms of the NIM ratio, there was a significant difference between Malaysia and Singapore at 0.79 percent, between Thailand and Singapore at 1.11 percent. Likewise, there is a difference between Indonesia and Singapore of 5.03 percent, between Indonesia and Malaysia at 4.24, between Indonesia and Thailand at 3.91 percent, and between Indonesia and the Philippines at 3.40. The Philippines also differs from Singapore by 1.63 and Philippines and Malaysia by 0.84 . Accordingly, there are differences between groups if tested with Post Hoc Test individually.

\section{Homogeneous Subset Test}

This test purposes to find out whether the banking financial performance group among ASEAN countries has a difference in average that is not significantly different which will be grouped into five different subsets. If there are no significant differences, the five samples will be grouped into one subset.

Based on estimate, it can be seen that the capital aspect described through the CAR shows a significance value of 0.247 which states that the average CAR between Philippines, Thailand, Malaysian and Singapore banks (in one subset) means that it is not statistically different. While the average value of CAR for Thailand, Singapore and Indonesian banks shows a significance value of 0.060 and is in a subset, which means that it is not statistically different, but if compared to Indonesian banks with the Philippines and Malaysian banks with different subset, it shows that the average value -The CAR is significantly different.

In the aspect of banking liquidity which is illustrated through the LDR, ratio shows a significance value of 1.00 which states that the average LDR of Philippines banks is in a subset of one, which means that it is statistically different from the other 4 ASEAN countries. While the average value of LDR for Indonesian and Singapore banks is in a subset of two in one subset which shows a significance value of 0.726 and is in a subset, which means that it is not statistically different. However, for Thailand and Malaysian banks which are in subset 3, the average LDR value between the two countries is not significantly different. In general, some countries have significant differences in the average value of the banking LDR.

The profitability aspect described through the ROA ratio shows a significance value of 0.164 which states that the average ROA between Singapore, Malaysia, Philippines, and Thailand banks (in one subset) which means that it is not statistically different while the average value of ROA for Indonesian banks is in a different subset column and shows significant differences with the other 4 ASEAN countries.

The NIM ratios of ASEAN-5 countries are grouped into four subsets, which means that some countries have significant differences to the other 4 ASEAN countries such as Singapore which is in column subset 1 and also Indonesia in the subset 4 column. Nonetheless there are also countries that do not have the difference in the average value of NIM that is not different from other countries such as Malaysia and Thailand which are in the same subset with a significance value of 0.598 there are also coincidence when Thailand and Philippines are in a subset with a significance value of 0.157 which means that the two countries do not have significant difference in NIM mean value.

As a result, based on Table 7 that shows the aspect of profitability for Indonesian banking ROA 
has the best results because the average value is above the average of the other four ASEAN banks. In addition to the NIM ratio, Indonesian banks also show the highest average rates compared to the other four ASEAN countries.

In general, it can be comprehended that the performance of banking finance in Indonesia is able to compete with other ASEAN countries. Most of Indonesia's financial ratios confirms better performance than the other four ASEAN countries, such as the CAR ratio, ROA ratio, and NIM ratio. But on the other hand in the aspect of banking liquidity which is illustrated through the LDR ratio, banking in Indonesia is still below the ASEAN banking average. Then for the digital banking index, Thailand has the highest value compared to four other countries that is 9.5005. The high index of a country's digital banking is in line with good banking performance. Conversely, countries with a low digital banking index were also accompanied by lower banking performance compared to other ASEAN countries, namely Malaysia and the Philippines.
Chow Test results, Hausman Test, and LM Test from the regression panel proved that common effects were the best model used in this study. Based on the results of the F test, all models have a significance value of 0.0000 because the significance level is less than 0.05 ( 5 percent). All models can be used to predict the dependent variable, NIM. In Table 8 the panel regression results are presented with the common effect model.

\section{Discussion}

Based on the regression results, there are only two variables independent that significant on financial performance of bank (NIM). The variables are index digital (DIGITAL) and funding from the third parties (DPK). Three other variables have not significant effect on banking financial performance. The prob. value of INFORMATION is 0.3513 while the coefficient value is 0.6554 . The prob. value of INFORMATION is greater than 5 percent which means that information of digital banking provided by the

Table 7. Comparison of Indonesian banking financial performance average and index digital banking with ASEAN countries

\begin{tabular}{lrrrrrr}
\hline \multicolumn{1}{c}{ Rasio } & Indonesia(\%) & Singapore(\%) & Malaysia(\%) & Thailand(\%) & Philippines(\%) & $\begin{array}{c}\text { Good/ } \\
\text { Not Good }\end{array}$ \\
\hline CAR & 18.254 & 16.62 & 15.862 & 16.46 & $\mathrm{~B}$ \\
LDR & 82.925 & 85.12 & 90.88 & 92.179 & 69.262 \\
ROA & 3.6413 & 1.038 & 1.2893 & 1.464 & $\mathrm{~KB}$ \\
NIM & 6.7467 & 1.7187 & 2.5073 & 2.8333 & 3.4547 \\
Index Digital & 8.0192 & 7.6815 & 6.1403 & 9.5005 & 3.3507 \\
Banking & & & & & 6.4315 \\
\hline
\end{tabular}

Table 8. The results of panel data estimation

\begin{tabular}{lccc}
\hline \multicolumn{1}{c}{ Variables } & Exp. & & Common Effect \\
\cline { 3 - 4 } & Sig & Coeff & Prob \\
\hline Independent & & & 0.6554 \\
INFORMATION & + & 0.1156 & 0.3513 \\
DIGITAL & + & 0.2913 & 0.0000 \\
USER & - & 0.0682 & 0.0768 \\
CREDIT & - & 0.4359 & 0.6312 \\
DPK & + & & 0.0002 \\
& & & 0.4094 \\
R-squared & & & 0.3823 \\
Adjusted R-squared & & & 15.1128 \\
F-statistic & & & 0.0000 \\
Prob(F-statistic) & & & \\
\hline
\end{tabular}


bank has no significant effect on the bank's financial performance. Users in internet banking of each banks in this study has prob. value 0.0768 that is greater than 5 percent which means the user has no significant effect on the bank's financial performance, especially on profitability. The prob. value of CREDIT as variable control is 0.6312 while the coefficient value is 0.0682 . The level of significance is greater than 5 percent which means that credit channel by the bank has no significant effect on the bank's financial performance.

The prob. value of DIGITAL is 0.0000 while the coefficient value is 0.1156 . The prob. value of DIGITAL is less than 5 percent or 0.05 which means that the index digital bank has a positive effect on the bank's financial performance. The control variable used as an independent variable and has an impact on bank profitability is the amount of funds of third parties. The prob. value of DPK is 0.0002 with coefficient is 0.435986 . The level of significance when viewed from the prob. value is less than $5 \%$, which means that the more the funds of third parties, it can improve bank financial performance in terms of profitability because the fund can be used not only for credit channel but also for investment that can give more profit on the bank.

$R^{2}$ value is 0.409420 or 41 percent, which means that the application of digital banking by banks in ASEAN-5 countries can explain the relationship on banking financial performance by 41 percent and the remaining 59 percent is influenced by other variables. This means that the implementation of digital banking has as not overly impact on banking financial performance, especially in profitability ratios.

In reality there are some people who prefer to conduct banking transactions directly through bank offices, especially for transactions that are complex and large scale. In addition, public knowledge, especially in developing countries such as ASEAN member countries, towards digital banks is not very good compared to developed countries such as in
America and Europe. The low level of confidence in the security of banking transactions via digital, and also banking technology readiness that has not been maximized is one of the obstacles to maximizing the role of digital banking towards the improvement of bank financial performance. This is indicated by not all communities, especially those who live in rural or remote areas, can access e-banking due to being hampered by signals or internet networks. Yang et al. (2018) states that the speed of ebanking services is strongly influenced by network speed. Besides that, digital banking is a long journey that takes time to adjust with digital strategies, overcome digital distractions (such as unstable internet connections), and takes time to improve bank features to suit the needs of customers (Deloitte tax \& consulting, 2017).

The banking sector is also challenged with the digital era so that its financial performance does not decline. First, increasingly fierce competition between banks for consumers can quickly and easily compare the same services and products among various banks and additional costs are needed to promote e-banking services provided by banks to attract consumers (Angelakopoulos \& Mihiotis, 2011; Okibo \& Wario, 2014). Second, banks face high risks to safeguard consumer privacy because privacy is the basis for electronic service quality standards and gives consumers a sense of security (Ibrahim, Joseph, \& Ibeh, 2006).

\section{Conclusion}

Comparison of the average banking financial performance in Indonesia shows good results, three of the four financial ratios studied show better results compared to the other four ASEAN countries. In the aspect of capital, the CAR ratio of 18.25 percent is better than Malaysia, Thailand, Philippines, and Singapore. In the aspect of profitability that is described by the ratio of ROA and NIM, the average value of ROA and NIM in Indonesia is also better compared to the other four ASEAN countries. 
The average value of Indonesian state ROA is 3.64 percent, and the average value of the NIM ratio shows a result of 6.75 percent. However, the liquidity aspect illustrated by the LDR ratio, the average financial performance value is 82.92 percent, which is not good compared to Singapore, Malaysia, and Thailand, even though it is better than the Philippines. There are significant dissimilarities between the banking financial performance ratios of ASEAN5 countries. Based on capital aspects, the CAR ratio shows the results of the most significant differences between Indonesia and Malaysia and the Philippines whereas the liquidity aspect illustrated by the LDR ratio shows a significant difference between Singapore and Philippines, Malaysia with Singapore, Indonesia, and Philippines, Thailand with Singapore, Indonesia, and Philippines, and Indonesia and Philippines. As for the aspects of profitability, the ROA and NIM ratios are described, on the ROA ratio significant differences occurred between Indonesia and the other four ASEAN countries and based on the NIM ratio a significant difference occurs between Malaysia and Singapore, Thailand and Singapore, Indonesia and four countries. Other ASEAN, as well as Philippines with Singapore and Malaysia. The current implementation of digital banking in the digital era has shown a fairly good influence on banking financial performance which particularly in profitability ratios in Indonesia, Singapore, Malaysia, Thailand and the Philippines. This is because the impact only 41 percent and can increase along with the development of an increasingly massive digitalization era. This is influenced by ASEAN, whose position is currently in the evolutionary phase of digital banking so that it still needs more time to develop and refine the digitalization system in all aspects of banking.

Findings of the research results may not represent the current conditions because the use and development of digital banking continues to increase significantly in each ASEAN country, so further research is needed with more complete data to perfect the research. In terms of dealing with the digital era, the banking sector needs to make improvements and development of low-cost technology to support digital banking services, strengthen the security system of bank networks to protect consumers and prevent losses that can be experienced by banks, as well as promote and socialize the public to know more, understand and can receive banking services online. In the long term, digital banking can have a major influence on financial performance, especially banking profitability as well as the condition of banks in developed countries, so that the banking sector in Indonesia is able to survive in the digital era and be able to compete on an international scale. Based on the limitations above, so it needs further research with more complete data such us transaction value of digital banking because in this research, not all samples provide the data.

\section{References}

Abdullah, F. (2003). Manajemen Perbankan. Malang: UMM Press.

Angelakopoulos, G., \& Mihiotis, A. (2011). E-banking: Challenges and opportunities in the Greek banking sector. Electronic Commerce Research, 11(3), 297-319. https://doi.org/10.1007/s10660-011-9076-2

Arnaboldi, F., \& Claeys, P. (2010). Innovation and performance of European banks adopting internet. Cass Business School Working paper series.

Akhisar, Ý., Tunay, K. B., \& Tunay, N. (2015). The effects of innovations on bank performance: The case of electronic banking services. Procedia-Social and Behavioral Sciences, 195, 369-375. https://doi.org/10.1016/j.sbspro.2015.06.336 
Financial banking performance of ASEAN- 5 countries in the digital era

Nazaruddin Malik, Arlini Oktavia, Muhammad Sri Wahyudi Suliswanto, Firdha Aksari Anindyntha

Asmirawati. (2010). Analisis pertumbuhan sektor perbankan di Indonesia tahun 2001-2008. Jurnal Ekonomi Pembangunan, 8(1), 215-222. https://doi.org/10.22219/jep.v8i1.3597

Bradley, J., Loucks, J., Jameson, P., O’ Connel K., \& Barbier, J. (2014). Reimagining the Digital Bank. Cisco and/ or its affiliates.

Deloitte Tax \& Consulting. (2017). Digital banking benchmark improving the digital performance. Deloitte Digital, 4-28.

Fajarini, D. (2017). Efisiensi perbankan indonesia dalam menghadapi ASEAN banking integration frameework. Thesis. Fakultas Ekonomi dan Bisnis, Universitas Lampung.

Ibrahim, E. E., Joseph, M., \& Ibeh, K. (2006). Customers perception of electronic service delivery in the UK retail banking sector. International Journal of Bank Marketing, 24(7), 475-493. https://doi.org/10.1108/02652320610712094

Iman, N. (2016). Financial Technology dan Lembaga Keuangan. Gathering Mitra Linkage Bank Syariah Mandiri Yogyakarta.

Mihalciuc, C. C., Apetri, A. N., \& Bonaventure, M. (2008). The importance of modern e-banks for development of new economy. The USV Annals of Economics and Public Administration, 8(1): 147-151.

Nastiti, G. P. (2010). Pengaruh kualitas aktiva produktif dan profitabilitas terhadap kinerja keuangan bank yang go public di Indonesia Tahun 2005-2009. Jurnal Ekonomi Pembangunan, 8(1), 235-246. https://doi.org/10.22219/jep.v8i1.3599

Okibo, B. W., \& Wario, A. Y. (2014). Effects of e-banking on growth of customer base in Kenyan Bank. International Journal of Research in Management and Business Studies, 1(1), 78-84.

Oyewole, O. S., Abba, M., \& El-Maude, J. G. (2013). E-banking and bank performance: Evidence from Nigeria. International Journal of Scientific Engineering and Technology, 2(8), 766-771.

Rahadiyan, I., \& Sari, A. R. (2019). Peluang dan tantangan implementasi fintech peer to peer lending sebagai salah satu upaya peningkatan kesejahteraan masyarakat Indonesia. Defendonesia, 4(1), 18-28.

Shaukat, M., \& Zafarullah, M. (2010). Impact of information on organizational performance: An analysis of quantitive performance indicators of Pakistan's banking and manufacturing companies. European Journal of Economics, Finance and Administrative Sciences, 16, 37-49.

Siddik, M. , N. , A., Sun, G., Kabiraj, S., Shanmugan, J., \& Yanjuan, C. (2016). Impacts of e-banking on performance of banks in a developing economy: Empirical evidence from Bangladesh. Journal of Business Economics and Management, 17(6), 1066-1080.

Simpson, J. (2002). The impact of the internet in banking: Observations and evidence from developed and emerging markets. Telematics and Informatics, 19(4), 315-330. https://doi.org/10.1016/s0736-5853(01)00019-3

Subuh, L., Zuhroh, I., \& Abdullah, M. F. (2016). Komparasi kinerja keuangan bank nasional dan bank asing tahun 2010-2014. Jurnal Ekonomi Pembangunan, 14(2), 204-217. https://doi.org/10.22219/jep.v14i2.3892

Sumra, S. H., Manzoor, M. K., Sumra, H. H., \& Abbas, M. (2011). The impact of e-banking on the profitability of banks: A study of Pakistani banks. Journal of Public Administration and Governance, 1(1), 31-38. https://doi.org/10.5296/jpag.v1i1.692

Suroso, G. T. (2015). Masyarakat Ekonomi Asean (MEA) dan Perekonomian Indonesia. Publikasi Badan Pendidikan dan Pelatihan Keuangan Kementrian Keuangan. 
Wahyuni, A., \& Sukirno, S. (2016). Analisis perbandingan kinerja keuangan perbankan ASEAN (Studi pada bank umum Indonesia, Thailand, dan Filipina). Nominal, Barometer Riset Akuntansi dan Manajemen, 5(2). https://doi.org/10.21831/nominal.v5i2.11720

Wulandari, D. A. (2015). Analisis perbandingan kinerja keuangan dengan pendekatan RGEC di negara ASEAN (Studi pada bank umum Indonesia, Malaysia, Thailand, dan Singapura tahun 2010-2014).Jurnal Ilmiah Mahasiswa FEB, 4(1).

Yang, S., Li, Z., Ma, Y., \& Chen, X. (2018). Does electronic banking really improve bank performance? Evidence in China. International Journal of Economics and Finance, 10(2), 82-94. https://doi.org/10.5539/ijef.v10n2p82 